\title{
FROM COMPOSITION SERIES
}

\section{Carissa Pobre}

Ateneo de Manila University

carissapobre@gmail.com

\section{About the Author}

Carissa Pobre is presently finishing her undergraduate degree in creative writing at the Ateneo de Manila University. Her work has been published in the National Book Development Board's BookWatch, Heights, and Transit. She lives in Quezon City. 
COMPOSITION 1 (EXERCISES FOR VOICE)

\begin{abstract}
Upon knowing I was being watched, I traced the little movements of my body and consciousness the minutes I was here. Even sitting down, my mind made things faster than my body. The iterations of profiles. The manner of seeing. Impress a filter upon a colored word. When I looked for my reflection, it was expressionless around me. Dim light edges off like the lure of a promise. The world made its few marks, they look back.
\end{abstract}


Their appearance is tangential, as a soft wind carries off smoke before it dissipates. Impressions left over. I understand an utterance as hollow form of participation, a little cry, being pressed on for its lack of thought. Most sounds I have heard want. The rough sketch of language eases into place, weight upon ground, until the light shifts, refraction of subject into shadow. A leaf falls. The rest is still. I feel my consciousness bloom. 
Underneath my feet a piece of fruit had been caught in the sifts of black ants. The blacker dirt had dried out from time of day. Words heave through syntax, so it doesn't surprise me now I have set your body onto air-elapse the body to nothing-form, collapse all height to the flat of level. My desire was deep but it was opaque across. Trying to speak, we are slightly shifting. Now water starts to drop on my left shoulder. 
Exercise for voice: an utterance rotting at the walls of the throat. Numbing from decay. Rusting from smoke. Whatever appears too still will be assumed to have died. All desire wants is to do away with itself. But to speak simply makes language impossible. I don't imagine every laceration is corruptive. It is deceptive to measure worth. No word more drained of color as the next. The sound my mind makes is quick and howling. 
The hollow mouth and hollow time deepen with promise but flatten out-what deceives to open, drawing back the syllable to the root. I don't resist this behavior. My voice swells in vacant air. And the prolonged stasis of the metaphor between us won't have slip the possibility of parting. Even if the body is so blurred those contours at which one gropes have dissipated. The utterance is earnest, dragging self-consciousness in. 
The voice resists dissipation trying to prolong worth, around me it becomes a thoughtless listening. In the pursuit of clear reflection, consider tracing presence from impression. I could tell I was being watched from the small glass panel of a door, upon which a shadow kept shifting. I understand conversation as a drowning. There are sounds in me heavy as notes. The forms collapse and the body takes its leave. I tell myself look onwards and wait. 
COMPOSITION 2 (ON CONVERSATION)

No one knows the cause, he says. There are rare phenomena that you have to be so close to the source to witness. Why don't you look outside the window till you see it. No one owns a polished stone on the street. Of course broken streets are empty. The crowd can't be bothered by cold air.

I am always suspected of a sickness, she says. All I want is to trust a man with plain, unshaken faith. I couldn't speak for days once. My mother came over many times like a beating. But some men form ash-heaps in their mouth with words. I wouldn't step outside. I'd dry out.

How old-fashioned, he says. I've seen other people go through their lives believing a laceration is a system of privacy. Even a brief pause becomes its own selfmachination. No such thing as mildness in utterance. Go and open up our presence, I don't care about that anymore.

There are many forms of dissonance, she says. I imagine I'd begin every conversation with white noise. Someone who has never stolen will not understand me. Someone who has never stolen and not felt love from being caught will not understand me. I told you then. I wouldn't change my mind now.

Anything they say now is toneless. So insert the mirror, like cleaving the natural color from a word. Opacity opposes the noise and voids the options. The project to be prolonged in terms of lack. 
Notes to Composition 2

Phonology. A whisper, if tenderness was a sound. But it clamors as if the utterance drowned. A howl. A cry. The body says it. And when he says he doesn't care, I try to feel its shape.

Syntax. She must be vanishing if she doesn't feel. I won't mind how loud or soft, I'll consider if it's far away. Taking place as a form of dirt. The thought won't last, like an echo or noise.

Semantics. The lightness of it-how it filled the room, from above me. I was sitting by the window, looking toward a blank, white sky. Ringing in my ear, faint melody like a lullaby haunting. 